Volume 11

Issue 3 Global Approaches to Atrocity

Prevention: Theory, Practice, and the State of

Article 7 the Field

$3-2018$

\title{
Why the United Nations Underperforms at Preventing Mass Atrocities
}

Edward C. Luck

Columbia University

Follow this and additional works at: https://digitalcommons.usf.edu/gsp

\section{Recommended Citation}

Luck, Edward C. (2018) "Why the United Nations Underperforms at Preventing Mass Atrocities," Genocide Studies and Prevention: An International Journal: Vol. 11: Iss. 3: 32-47.

DOI:

http://doi.org/10.5038/1911-9933.11.3.1516

Available at: https://digitalcommons.usf.edu/gsp/vol11/iss3/7

This Articles is brought to you for free and open access by the Open Access Journals at Digital Commons @ University of South Florida. It has been accepted for inclusion in Genocide Studies and Prevention: An International Journal by an authorized editor of Digital Commons @ University of South Florida. For more information, please contact digitalcommons@usf.edu. 


\section{Introduction}

If the United Nations always succeeded or never succeeded in preventing atrocity crimes, then there would be no point in trying to improve its performance. Instead, its track record has been remarkably uneven. Its quiet successes at preventing mass violence have been more than matched by horrific and well-publicized failures to prevent (or protect). ${ }^{1}$ Though it is impossible to measure prevention with any degree of certainty, it appears that the world body has, on occasion, made a positive difference. ${ }^{2}$ So, it has potential. But, in too many situations, that potential has not been realized. This essay asks why the UN's preventive efforts have been so inconsistent and how some of the shortcomings in its performance might be remedied.

At the outset, this paper makes three assumptions. One, over the years, the United Nations has been no worse at preventing mass atrocities than have been regional and sub-regional organizations, governments, and/or civil society. Two, when prevention has worked, it has generally been because there has been productive collaboration among actors of these various types and levels, so credit or blame should be shared. Three, nevertheless, mediocrity on any actor's part is not an acceptable standard when it comes to an issue of public policy with such existential implications for human life.

This essay argues further 1) that the United Nations has a unique combination of assets that could be put to much better use in this area, 2) that shortcomings in its performance arise as much from conceptual misunderstandings and institutional dysfunction as from capacity deficits, 3) that these shortcomings have negative implications for whether and how effectively other critical actors respond to the atrocity prevention challenge, and 4) that steps could be taken to improve the situation significantly without a huge infusion of scarce resources. These points are addressed in the following four sections on potential, shortcomings, implications, and remedies, respectively.

\section{Potential}

International efforts to prevent mass atrocity crimes require four core elements: legitimacy, authority, capacity, and strategy. Legitimacy is the ability to generate and sustain political support on the local, national, and regional, as well as international, levels for the preventive measures being undertaken or contemplated and for the purposes being served. Authority, which may buttress legitimacy, derives from those legal instruments and institutional decision-making processes that confirm that those preventive actions are appropriate to the circumstances and proportional to the purposes being pursued. Capacity refers to having and/or mobilizing and being able to employ the requisite physical, material, financial, and human resources to carry out the preventive measures fully and effectively. Strategy relates to the ability to assess and frame the unfolding situation

\footnotetext{
${ }^{1}$ For the purposes of this paper, mass atrocity crimes are considered to be those identified under United Nations, General Assembly Resolution 60/1, 2005 World Summit Outcome, October 24, 2005 (UN Doc. A/RES/60/1), paragraph 138, its discussion of the Responsibility to Protect, namely genocide, war crimes, ethnic cleansing, and crimes against humanity. The terms atrocity and mass atrocity are used inter-changeably in this paper.

${ }^{2}$ In his 2015 and 2016 reports on the Responsibility to Protect (R2P), UN Secretary-General Ban Ki-moon noted that preventive efforts by the United Nations and its partners had helped to prevent mass atrocity crimes and/ or their escalation in Côte d'Ivoire, Guinea, Kenya, Kyrgyzstan, and Timor-Leste. United Nations, Report of the Secretary-General, A Vital and Enduring Commitment: Implementing the Responsibility to Protect, July 13, 2015 (UN Doc. A/69/981-S/2015/500), para. 8; United Nations, Report of the Secretary-General, Mobilizing Collective Action: The Next Decade of the Responsibility to Protect, July 22, 2016 (UN Doc. A/70/999-S/2016/620), paras. 33 and 55. Twelve chapters of the 2016 Oxford Handbook of the Responsibility to Protect are devoted to situations in which mass atrocity crimes occurred or were prevented. See Alex J. Bellamy and Tim Dunne, eds., Oxford Handbook of the Responsibility to Protect (Oxford: Oxford University Press, 2016), 693-910. Also see Naomi Kikoler, "Guinea: An Overlooked Case of the Responsibility to Protect in Practice," in The Responsibility to Protect: Overcoming the Challenge of Atrocity Prevention, eds. Serena K. Sharma and Jennifer M. Welsh (Oxford: Oxford University Press, 2015), 304-323.
} 
and the players involved both in a timely manner and from an atrocity prevention perspective, to develop an effective plan for response to developments on the ground, to build a sustainable coalition of actors on all levels willing to pursue the same objectives in a mutually reinforcing manner, and to reassess and adjust the strategy as needed in the face of unexpected developments. Ultimately, prevention is not completed until steps are taken to discourage a reoccurrence of such threats of mass atrocities.

Legitimacy should be one of the United Nations' prime attributes. The 193-member General Assembly, the world's only virtually universal political body, has endorsed both the Genocide Convention and the Responsibility to Protect (R2P). Though its decisions--other than on internal matters - are not legally binding, the Assembly has, from its earliest days been the world's prime incubator of global norms and standards. Since 2009, the Assembly's annual informal interactive dialogues on R2P have shown broad and persistent support from the Member States for the preventive dimensions of $\mathrm{R} 2 \mathrm{P}$, even as some delegations continue to express reservations about possible coercive measures under the third pillar of the Secretary-General's implementation strategy (as crafted by this author). ${ }^{3}$ Successive Secretaries-General have produced a series of well-received reports on conflict prevention, something which António Guterres has pledged to make the centerpiece of his tenure. ${ }^{4}$ In many cases, moreover, the United Nations is more likely to be perceived as a disinterested actor than would neighbors or more distant but powerful states. Perceptions of impartiality should bolster claims to legitimacy. Multilateral measures are generally assumed to be more legitimate than unilateral ones, as long as the measures undertaken by the UN (or a regional body) are not perceived as being manipulated by a few powerful Member States to further narrow national interests.

Authority should be another advantage for the world body. Its Charter gives the United Nations ample legal authority for initiating preventive efforts and for building global-regional partnerships to do so, as well as historically unprecedented authority for undertaking multilateral enforcement action. Prevention is the first purpose mentioned in the Charter and Chapter VI lays out a wide range of non-coercive tools for preventing and resolving conflict. Chapter VIII defines the modalities for collaboration with regional arrangements in these pursuits, while Chapter VII outlines the Security Council's unsurpassed and historically unique enforcement powers.

Though enforcement is often thought of solely in terms of coercive military action, there are a wide range of sanctions - relating to diplomatic, political, financial, and economic measures, as well as restrictions on military assistance and arms transfers - that could be employed with greatest effect early in a crisis for preventive and/or deterrent purposes, whether targeted on individual, group, or national actors. Multilateral sanctions tend to be much more persuasive than unilateral ones, so getting Security Council authorization can be an essential step. In the context of atrocity prevention, it should be recalled that the Council's enforcement powers override the constraints on intervening in essentially domestic matters noted in Article 2 (7). Though the Charter is silent on genocide and mass atrocities, it is replete with multiple references to promoting and encouraging respect for human rights and fundamental freedoms. In that regard, the Security Council has the authority to make referrals to the Intrnational Criminal Court (ICC), a non-UN body, concerning the alleged commission of atrocity crimes. In a number of situations, UN representatives have reminded local and national actors of this possibility.

${ }^{3}$ In 2009, the General Assembly held both a short informal interactive dialogue and then a formal debate on the Secretary General's report, Implementing the Responsibility to Protect, of 12 January 2009, which laid out his three-pillar strategy. United Nations, Report of the Secretary-General, Implementing the Responsibility to Protect, January 12, 2009 (UN Doc. A/63/677). This author was the architect of the strategy and the principal drafter of that report and all other statements and reports by the Secretary-General on R2P from 2007 to mid-2012. Each year since 2009, the Secretary-General has produced a report on different aspects of R2P to be addressed at informal interactive dialogues of the General Assembly. The reports and summaries of the dialogues can be found on the web sites of the Global Centre on the Responsibility to Protect and of the International Coalition for the Responsibility to Protect.

${ }^{4}$ The first major report, by Secretary-General Kofi Annan, was United Nations, Report by the Secretary-General, Prevention of Armed Conflict, June 7, 2001 (UN Doc. A/55/985-S/2001/574). More recently, see António Guterres, "SecretaryGeneral-Designate Remarks to the General Assembly on Taking the Oath of Office" (speech, New York, December 12, 2016) United Nations. 
It is commonplace to observe that the United Nations' claims to legitimacy and authority are not matched by a reliable capacity to carry out its decisions and to forward its values. There is much to this observation. However, this is more a commentary on its capacity for response than for prevention, given that a coercive response under Chapter VII requires the mobilization of the economic and/or military capacities of the Member States, as well as authorization by the Security Council. The organization's capacities for preventive action under Chapter VI and Article 99 (see below)-even if only undertaken by the Secretary-General, the Secretariat, or other parts of the UN system - do not necessarily depend on explicit action by the Member States. These preventive capacities are quite varied and broad, if not deep or robust.

In terms of structural or upstream prevention, the UN system has a presence, whether for sustainable development, humanitarian, human rights, peacebuilding, peacekeeping, and/or conflict resolution purposes, in most of the countries of potential concern. In terms of operational or more immediate preventive measures, when endorsing R2P at the 2005 World Summit, the gathered heads of State and government agreed to support the United Nations "in establishing an early warning capacity" and to assist States "under stress before crises and conflicts break out." $^{5}$ Though the Summit authorized the establishment of a Peacebuilding Commission (PBC) limited to post-conflict scenarios, it should be recalled that the initial proposal for the Commission, introduced by Secretary-General Kofi Annan's High-level Panel on Threats, Challenges and Change in late 2004, envisioned it having an R2P-like preventive function as well. The first core function for the Commission, according to the High-level Panel, should be "to identify countries which are under stress and risk sliding towards State collapse" and "to organize, in partnership with the national Government, proactive assistance in preventing that process from developing further." 6 The substantive parallels to the R2P language on assisting states under stress are striking. Yet the fact that the preventive dimension of the PBC was not retained in the Summit articulation of the purposes of the $\mathrm{PBC}$ is suggestive of the political hurdles that have to be overcome in some cases of structural and operational prevention, as well as in crafting effective responses to unfolding atrocities.

In terms of operational prevention, under Article 99 of the Charter the Secretary-General "may bring to the attention of the Security Council any matter which in his opinion may threaten the maintenance of international peace and security." ${ }^{7}$ Since 2009, this clause has increasingly been interpreted as including the potential commission of mass atrocity crimes, whether in statements to the Council by the Secretary-General, his Special Advisor for the Prevention of Genocide, or the High Commissioner for Human Rights. ${ }^{8}$ The bully pulpit that the Secretary-General and his small army of SRSGs (Special Advisers, Special Representatives, and Envoys) share can be critical to getting preventive messages to would-be perpetrators, bystanders, vulnerable populations, media, civil society leaders, governments, and regional arrangements. These messages have often been about discouraging the incitement of atrocity crimes, something which all of the world leaders agreed at the 2005 World Summit to prevent (paragraph 138 of the Outcome Document). In this author's experience, pushing back against indications of incitement has proven to be one of the most flexible and timely tools in the prevention toolkit.

\footnotetext{
${ }^{5}$ United Nations, 2005 World Summit Outcome, paras. 138 and 139, respectively.

${ }^{6}$ United Nations, Report of the Secretary-General's High-level Panel on Threats, Challenges and Change, A More Secure World: Our Shared Responsibility, 2004 (United Nations Department of Public Information), 83, para. 264.

${ }^{7}$ United Nations, Charter of the United Nations and Statute of the International Court of Justice, June 26, 1945 (United Nations), article 99.

${ }^{8}$ The inclusion of the four R2P crimes under Article 99 was proposed by this author to the Security Council's Ad Hoc Working Group on Conflict Prevention and Resolution in Africa in December 2008. This has since become common practice. United Nations Security Council, Letter Dated 30 December 2008 from the Permanent Representative of South Africa Addressed to the President of the Security Council, December 31, 2008 (UN Doc. S/2008/836), 13. Also see Simon Chesterman, "Relations with the Secretary-General," in The UN Security Council in the $21^{\text {st }}$ Century, eds. Sebastian von Einsiedel, David M. Malone, and Bruno Stagno Ugarte (Boulder: Lynne Rienner, 2016), 453. In his final report on R2P, Secretary-General Ban Ki-moon noted that "when the situation has required it, I have informed the Security Council of atrocity crime risks and urged it to take early and decisive action. My hope is that future Secretaries-General will continue to draw on the authority provided to them under the Charter of the United Nations." United Nations Secretary-General, Mobilizing Collective Action, 11, para. 39.
} 
Strategy, perhaps more than the other core dimensions, is an area under construction. Though the General Assembly approved the Genocide Convention almost seventy years ago, the first UN plan to prevent genocide was not articulated until 2004 to mark the tenth anniversary of the Rwandan genocide (discussed more fully below). ${ }^{9}$ Since 2009, the Joint Office on Genocide Prevention and the Responsibility to Protect has developed an all-encompassing Framework for Analysis for the Prevention of Atrocity Crimes and the Secretary-General's annual reports on different aspects of R2P have placed a heavy emphasis on prevention. Though the UN was late to framing concepts and strategies for preventing atrocity crimes, so too were governments, regional organizations, and academia. In the 1990s, however, the UN was at the forefront of the articulation of concerns about human security and human protection that continue to provide an intellectual and political context for atrocity prevention. ${ }^{10}$ This intellectual heritage suggests that the world body is in a position to develop a broader and more multilateral framework for preventing and responding to mass atrocity crimes beyond the narrower perspectives of some governments, much as it did in the case of counter-terrorism following the attacks of 9/11.

\section{Shortcomings}

It would be tempting, but overly sweeping and simplistic, to assert that the primary reason for the UN's underperformance in atrocity prevention has been because of the narrow domestic and geopolitical agendas of powerful Member States. This may be the case in places, such as Syria, Sudan, or Yemen, where the geopolitical stakes are perceived to be high and the UN's entreaties have fallen on deaf ears. The UN's preventive efforts may well have had more success in low profile cases on the whole than in high profile ones in which there have been more actors of significance. Yet the UN has done relatively well in some places, such as Kyrgyzstan and Kenya, where the stakes were high geopolitically and relatively poorly in others, such as Sri Lanka and Central African Republic, where the international stakes were modest.

It may well be that the 193 Member States are simultaneously the greatest strength and the greatest weakness of the United Nations. Either way, forging their collaboration on matters of common concern was a founding purpose of the organization. So it is not enough for the Secretariat-or for capitals or civil society-- just to lament the differences among key Member States and declare some situations to be too politically sensitive to handle, especially when there appears to be an imminent threat of mass atrocity crimes. The inter-governmental bodies provide the mandates that the Secretariat has an obligation to implement, but the latter cannot be passive bystanders to the political process. Their responsibilities are not limited to narrow interpretations of the specific mandates they are assigned by the inter-governmental bodies.

UN officials are obligated both to act to further the principles and purposes of the Charter and, as noted above, to inform the Security Council of possible threats to international peace and security under Article 99 of the Charter. The latter entails taking proactive steps to gather and assess the information needed to provide the Council and other relevant organs with the Secretariat's informed and considered judgements about situations of concern. As the 2000 Brahimi peacekeeping report famously commented, in the context of mass atrocity prevention, the Secretariat has an obligation to tell the Security Council what it needs to hear, not what it wants to hear. ${ }^{11}$ Too often, the Secretariat engages in pre-emptive self-censorship, trimming their analytical sails before even testing the direction and velocity of the political winds. (There have also been occasions, of course, when the Secretariat has exaggerated risks and potential casualties.)

\footnotetext{
${ }^{9}$ The reasons for this delay are discussed in Edward C. Luck, "Roots of Ambivalence: The United Nations, Genocide, and Mass Atrocity Prevention," in Policies and Practices for Preventing Atrocities, eds. Ted Robert Gurr and Barbara Harff (London: Routledge, forthcoming).

${ }^{10}$ Tellingly, genocide prevention and mass atrocity prevention - the latter under the rubric of R2P--were among the last entries in a long list of human protection concerns adopted by the UN. They were preceded, among other concerns, by humanitarian assistance, internal displacement, children and armed conflict, sexual and gender-based violence, women, peace, and security, and civilian protection in peacekeeping contexts. See Chapter One of Alex J. Bellamy and Edward C. Luck, The Responsibility to Protect: From Promise to Practice (Cambridge, UK: Polity Books, forthcoming).

${ }^{11}$ United Nations, Report of the Panel on United Nations Peace Operations, August 21, 2000 (UN Doc. A/55/305-S/2000/809).
} 
The long tradition of blaming the Member States for every UN failing has done little to enhance understanding of how to improve the organization's performance, especially in areas, such as atrocity prevention, in which the Secretariat could, and often does, play a major operational role. The Security Council's growing willingness to hear from the Secretariat-and, in informal settings, from civil society - about potential atrocity crimes has been an important step forward, but much more could be done in the future to make this a more regular feature of Secretariat-Member State collaboration. ${ }^{12}$ Little attention, for instance, has been given to the roles the General Assembly, the Peacebuilding Commission, and the Human Rights Council could play in forwarding the atrocity prevention agenda.

Though the Assembly, under Article 12 (1) of the Charter, may not make recommendations on matters being addressed by the Council, it may discuss or investigate any matter. It has, for instance, passed several pointed resolutions on Syria, reflecting broad frustration among the Member States about the blockages within the Council on the situation. ${ }^{13}$ Under the Uniting for Peace formula, the Assembly has a long history of authorizing peace operations under Chapter VI of the Charter. ${ }^{14}$ Though such operations would not have an enforcement mandate, they might play a useful function as preventive deployments in places where there are real possibilities of instability and atrocity crimes. Under Article 11 (3) of the Charter, the Assembly has the equivalent of Article 99 authority for referring threats to the Council. As noted earlier, the Assembly has been the locus for efforts to refine R2P and to build broader Member State support for it. But it has also been the forum for frustrating attempts to gain the human and financial resources needed to mount a proper and sustainable effort to prevent atrocity crimes. For instance, a small minority in the Assembly's Fifth Committee has been able-or allowed - to repeatedly block the provision of even very modest capacities to implement R2P, despite its endorsement at the highest levels at the 2005 World Summit.

As noted above, the Peacebuilding Commission (PBC) was originally conceived as an intergovernmental body that could deal with countries either sliding into or emerging from conflict. It was established as a subsidiary advisory body both of the General Assembly and of the Security Council. ${ }^{15}$ Though its pre-conflict function was dropped, it could still have a preventive role in helping societies that had suffered sectarian violence from repeating the cycle. This could be a significant preventive measure, as it has long been said that the best predictor of genocide is past genocide. In its country-specific configuration, the PBC could potentially help draw economic and political resources to situations of atrocity concern that have not received much international attention. In practice, however, there has been relatively little overlap between the countries on which the PBC has focused and those of highest priority from an atrocity prevention viewpoint. As a 2015 review of the PBC underscored, for a variety of political and institutional reasons, it has not been able to realize its potential for strategic leadership or for bridging the gaps between the Security Council and the General Assembly. ${ }^{16}$

The Geneva-based Human Rights Council came rather late to the R2P debate for both political and geographical reasons. However, the Council's Commissions of Inquiry on the Democratic

${ }^{12}$ Alex J. Bellamy, "UN Security Council," in Oxford Handbook of the Responsibility to Protect, eds. Alex J. Bellamy and Tim Dunne (Oxford: Oxford University Press, 2016), 249-268; Edward C. Luck, "Prospects for Institutional Renovation and Reform," in The Oxford Handbook on the United Nations, 2nd ed., eds. Thomas G. Weiss and Sam Daws (Oxford: Oxford University Press, forthcoming).

${ }^{13}$ The General Assembly, for instance, authorized the creation of a mechanism to investigate the alleged commission of atrocity crimes in Syria. United Nations, Resolution Adopted by the General Assembly on 21 December 2016 (UN Doc. A/ RES/71/248).

${ }^{14}$ Dominik Zaum, "The Security Council, the General Assembly, and War: The Uniting for Peace Resolution," in The United Nations Security Council and War: The Evolution of Thought and Practice Since 1945, eds. Vaughan Lowe, et al. (Oxford: Oxford University Press, 2008), 154-174.

${ }^{15}$ United Nations, General Assembly Resolution (UN Doc. A/RES/60/1180); United Nations, Security Council Resolution 1645 on Post-conflict Peacebuilding, 2005 (UN Doc. 1645).

${ }^{16}$ United Nations, Identical Letters Dated 29 June 2015 from the Chair of the Advisory Group of Experts on the Review of the Peacebuilding Architecture Addressed to the President of the General Assembly and the President of the Security Council, June 30, 2015 (UN Doc. A/69/968-S/2015/490); United Nations, The Challenge of Sustaining Peace, Report of the Advisory Group of Experts on the Review of the Peacebuilding Architecture, June 30, 2015 (UN Doc. A/69/968-S/2015/490). 
People's Republic of Korea (DPRK) and on Syria have both been outspoken about the growing evidence of mass atrocity crimes, and the former invoked R2P and called on the international community to address the dire human protection situation in the DPRK more vigorously. ${ }^{17}$ In late 2016, the Russian Federation failed to be elected by the General Assembly to membership in the Human Rights Council, purportedly because of widespread concerns about the commission of atrocity crimes in Syria. ${ }^{18}$ From the passage by the General Assembly of the Genocide Convention and the Universal Declaration of Human Rights a day apart in 1948, these two agendas have followed parallel, not convergent, paths. ${ }^{19}$ Mutual respect and common purpose have been combined with a sense of ambiguity and even ambivalence about the relationship between atrocity crimes and human rights. ${ }^{20}$ In terms of implementation, the relatively large Office of the High Commissioner for Human Rights in Geneva and its much smaller cousin addressing genocide prevention and R2P in New York have tended to have distinct perspectives on reporting and institutional matters, even as they generally have viewed specific situations from similar but not congruent perspectives. ${ }^{21}$ It was this author's experience that the human rights conditions in a country were not always indicative of its proclivity to mass violence. Some chronic human rights violators were relatively stable, while some societies that were not among the worst violators, such as Kenya and Kyrgyzstan, nevertheless witnessed sudden violence and atrocity crimes.

The pursuit of human rights is not the only seemingly natural partner for atrocity prevention in which the relationship has had dysfunctional elements. In the case of humanitarian affairs, the differences have run deeper, based on divergent conceptual and political assumptions that are not easily reconciled. R2P, in particular, has not been embraced by many in the humanitarian community because of its inclusion of the use of coercive military force as a response option in extreme situations. As Hugo Slim has put it, the concerns of humanitarian actors about the third pillar of the Secretary-General's R2P implementation strategy "focus on four issues: the politicization of civilian protection; raised expectations that tend to freeze conflicts and postpone peace-making; the likely failure of force and the widening of conflict; and the contamination of humanitarian agencies by association." 22

From an atrocity prevention or R2P perspective, the emphasis in humanitarian principles on maintaining impartiality and preserving humanitarian space and access may entail prioritizing the cultivation of good relations with the very regimes that may be committing or planning to commit mass atrocities against their populations. These differences came to a head in the shaping of the UN Secretariat's response-the Security Council largely stayed on the sidelines--to the mounting violence targeted at civilians in the concluding phases of the civil war in Sri Lanka in late 2008-early 2009. It was decided at the upper reaches of the Secretariat that the situation should be framed as a humanitarian emergency, with the Emergency Relief Coordinator and the Office for Coordination of Humanitarian Affairs (OCHA) put in charge. R2P and genocide prevention perspectives were

${ }^{17}$ United Nations Human Rights Council, Report of the Commission of Inquiry on Human Rights in the Democratic People's Republic of Korea, February 7, 2014 (UN Doc. A/HRC/25/63) and Detailed Findings (UN Doc. A/HRC/25/CRP.1).

${ }^{18}$ It is highly unusual for one of the five permanent members of the Security Council to lose such a vote. Julian Borger, "Russia Denied Membership of UN Human Rights Council," The Guardian, 28 October 2016.

${ }^{19}$ It took several decades for human rights to gain a solid foothold in the UN Secretariat, and the first UN High Commissioner for Human Rights was not appointed until 1993, 45 years after the Universal Declaration. Genocide prevention took even longer, not gaining any presence in the Secretariat until 2004, as discussed below.

${ }^{20}$ For largely historical reasons, the ten human rights treaty bodies addressed by the Human Rights Council do not include the Genocide Convention. United Nations, Report of the Secretary-General, Status of the Human Rights Treaty Body System, July 18, 2016 (UN Doc. A/71/118), 2, para. 1. For the negotiating history of the Genocide Convention and the singular role of Raphael Lemkin, see James Waller, Confronting Evil: Engaging the Responsibility to Prevent Genocide (Oxford: Oxford University Press, 2016), 15-23 and Samantha Power, "A Problem from Hell:" America and the Age of Genocide (New York: Harper Collins, 2002), 51-60. For a discussion of the reluctance of the UN founders to embrace genocide or atrocity prevention, see Luck, Roots of Ambivalence.

${ }^{21}$ The appointment in 2010 of an Assistant Secretary-General to head the High Commissioner's office in New York has enhanced the opportunities for collaboration.

${ }^{22}$ Hugo Slim, "Saving Individuals from the Scourge of War: Complementarity and Tension between R2P and Humanitarian Action," in Oxford Handbook of the Responsibility to Protect, eds. Alex J. Bellamy and Tim Dunne (Oxford: Oxford University Press, 2016), 555. 
not welcome in the deliberations, reports of mounting human rights violations were dismissed, and the UN's voice was muted as the war crimes unfolded. ${ }^{23}$

The internal review of the organization's failures in the Sri Lankan crisis was candid about its shortcomings and pointed to a number of areas needing improvement. The primary institutional response was the enunciation of the Rights Up Front Action Plan by Secretary-General Ban in September 2013. ${ }^{24}$ The Plan had many positive elements, including the development of more coherent and streamlined means of collecting and integrating information on serious human rights violations into crisis response planning at UN headquarters. From an atrocity prevention perspective, however, the results have been more mixed. The differences in perspective between the humanitarian and atrocity prevention views of the crisis in Sri Lanka were finessed rather than confronted.

As Andrew Gilmour, at the time a key official in the Office of the Secretary-General and now Assistant Secretary-General for Human Rights in New York, put it: "those involved in formulating the initiative avoided getting into what was seen as an unproductive debate on the distinction between the 'protection of civilians' and the 'protection of human rights,' as Rights up Front is committed to both." ${ }^{25}$ He goes on to note the common emphasis in Rights Up Front and R2P on prevention and to underscore the concerns of some Member States with the possibility of using force under an R2P banner. ${ }^{26}$ Though the use of force was never a desirable or feasible alternative in Sri Lanka, the 1999 reports on the UN's failures to act in a timely and decisive manner in the Rwandan genocide and the massacre at Srebrenica highlighted the consequences of the UN's reluctance to take decisive military action when atrocity crimes were unfolding and it was a feasible option. ${ }^{27}$

The Rights Up Front initiative had significant implications, as well, for decision-making in the upper echelons of the Secretariat. A Senior Action Group (SAG) was established, chaired by the Deputy Secretary-General, to review a range of ongoing crises and to insure that human rights perspectives were taken into account. Though probably a net positive for atrocity prevention, SAG added little in those cases in which violence was not necessarily preceded by an escalation of human rights abuses. It also helped to ease the demise of the Policy Committee, a high-level group that had been chaired by the Secretary-General and that permitted more opportunities for his Special Advisers to present the case for addressing particular situations from an atrocity prevention perspective. This author's experience suggests that there are risks in imposing any barriers to the direct access of those mandated to prevent atrocity crimes to the Secretary-General or in creating distance between the Secretary-General and his/her personal responsibility for acting to try to prevent such crimes. ${ }^{28}$ That, after all, should have been one of the primary lessons from Sri Lanka.

\footnotetext{
${ }^{23}$ The report of the Secretary-General's Internal Review Panel on UN Action in Sri Lanka of November 2012 was never published, but it can be found on line (with some sections redacted). Also see Kimberly Nackers, "Framing the Responsibility to Protect in the 2009 Sri Lanka Civil War," Global Responsibility to Protect 7, no. 1 (2015), 81-108; Kimberly Nackers, "Sri Lanka," in Oxford Handbook of the Responsibility to Protect, eds. Alex J. Bellamy and Tim Dunne (Oxford: Oxford University Press, 2016), 876-894; Damien Kingsbury, "Sri Lanka," in The Responsibility to Protect: The Promise of Stopping Mass Atrocities in Our Time, eds. Jared Genser and Irwin Cotler (Oxford: Oxford University Press, 2012), 298-315; Edward C. Luck and Dana Zaret Luck, "The Individual Responsibility to Protect," in Reconstructing Atrocity Prevention, eds. Sheri P. Rosenberg, Tibi Galis, and Alex Zucker (New York: Cambridge University Press, 2016), 237-242.

${ }^{24}$ The "Rights Up Front" Detailed Action Plan prepared by the Inter-Agency Standing Committee, dated March 2014, is available online, though it is marked as an internal document. For a highly favorable view, see Gerrit Kurtz, With Courage and Coherence: The Human Rights Up Front Initiative of the United Nations, (Berlin: Global Public Policy Institute, July 2015).

${ }^{25}$ Andrew Gilmour, "The Future of Human Rights: A View from the United Nations," Ethics E International Affairs, 28, no. 2 (2014), 240-241.

${ }^{26}$ Ibid., 246-247.

${ }^{27}$ United Nations, Report of the Independent Inquiry into the Actions of the United Nations during the 1994 Genocide in Rwanda, December 16, 1999 (UN Doc. S/1999/1257); United Nations, Report of the Secretary-General pursuant to General Assembly Resolution 53/35: The Fall of Srebrenica, November 15, 1999 (UN Doc. A/54/549).

${ }^{28}$ The author introduced the notion of an Individual Responsibility to Protect (IR2P) into the Secretary-General's 2009 R2P implementation strategy. The concept is explained at greater length in Luck and Luck, The Individual Responsibility to Protect.
} 
Another potential asset-the presence of UN peacekeepers on the ground-has proven to be a mixed blessing. The record has been inconsistent. In Rwanda, Srebrenica, Sierra Leone, Darfur, and the Democratic Republic of the Congo (DRC), mass atrocities occurred despite the presence of UN forces. A moral hazard can be created when the promise of protection is not matched by commensurate action by those institutions and countries with the capacity to offer protection, as with the Security Council's declaration of safe areas in Bosnia-Herzegovina. ${ }^{29}$ Yet in Mozambique, Cambodia, the Former Yugoslav Republic of Macedonia, Côte d'Ivoire, and Mali, the blue helmets helped to prevent mass atrocities or their reoccurrence. In Kenya (twice), Kyrgyzstan, and Guinea (Conakry), preventive efforts prevailed without an international force on the ground. In South Sudan, peacekeepers have provided shelter for hundreds of thousands of civilians even as mass atrocities escalated elsewhere.

Given this mottled history, it is not surprising that the United Nations has developed distinct, if related, doctrines for the protection of civilians (POC) in a peacekeeping context and for mass atrocity prevention and R2P. ${ }^{30}$ Those in charge of peacekeeping at the $\mathrm{UN}$ have tended to be quite cautious about R2P for both political and conceptual reasons and about adding atrocity prevention tasks to already ambitious mandates for over-stretched peacekeeping operations. ${ }^{31}$ The United Nations, at this point, does not have a well-developed doctrine for the use of force, with or without consent, for the explicit purpose of protecting civilians from atrocities or of deterring such crimes. ${ }^{32}$ It has relatively few cases from which to draw lessons and these scattered experiences have been quite disparate. As Paul Williams puts it, "while it is understandable that the main practitioners of POC (UN peacekeepers and the Secretariat) would like this agenda to remain as uncontroversial as possible, pretending that these mandates can ignore the four R2P crimes or that they do not arise from a similar sentiment as R2P-inspired military intervention is not helpful. Avoidance is not the solution." ${ }^{33}$

This conceptual muddle has not been simplified or clarified by the growing recognition that non-state armed groups are - and have long been - among the more virulent perpetrators of atrocity crimes. In 2008, when this author was Special Adviser, he introduced armed groups, including those practicing terrorism, into the UN's R2P lexicon, which previously had focused entirely on governments as the sole perpetrators. ${ }^{34}$ Now, however, there is a real danger that concerns about preventing mass atrocity crimes could be distorted or overwhelmed by the much larger narrative and more widely embraced policy agenda on counter-terrorism. It is not entirely reassuring, in that regard, that the first time that a Security Council meeting directly addressed R2P was in a counterterrorism context or that the Secretary-General's 2015 report on conflict prevention included a

${ }^{29}$ On moral hazard, see Alan J. Kuperman, “The Moral Hazard of Humanitarian Intervention: Lessons from the Balkans," International Studies Quarterly, 52, no. 1 (March 2008), 49-80. On safe areas, see Phil Orchard, "Revisiting Humanitarian Safe Areas for Civilian Protection," Global Governance, 20 (2014), 55-75.

${ }^{30}$ Paul D. Williams, "The R2P, Protection of Civilians, and UN Peacekeeping Operations," in Oxford Handbook of the Responsibility to Protect, eds. Alex J. Bellamy and Tim Dunne (Oxford: Oxford University Press, 2016), 524-544.

${ }^{31}$ Jean-Marie Guéhenno, the able Under Secretary-General for Peacekeeping Operations from 2000-2008, has asserted that talk about possible humanitarian intervention had made it more difficult to obtain consent to a more traditional peacekeeping deployment in Darfur and that the use of force in Libya had stiffened Chinese and Russian resistance to effective action in Syria. He also argues, unconvincingly from this author's experience, that those countries favoring R2P are less likely to commit forces than those taking a more negative stance in the annual R2P debates in the General Assembly. Jean-Marie Guéhenno, The Fog of Peace: A Memoir of International Peacekeeping in the $21^{\text {st }}$ Century (Washington, DC: Brookings Institution Press, 2015), 186, 286, 310, and 305, respectively.

${ }^{32}$ Nevertheless, since the Secretary-General's first report on R2P in early 2009, the Security Council has authorized robust military enforcement measures at least in part for human protection purposes in six situations (all in Africa): Côte d'Ivoire (resolutions 1933 (2010), 1962 (2010), 1967 (2011), and 1975 (2011)); Libya (resolution 1973 (2011)); Mali (resolution 2100 (2013)); CAR (resolution 2127 (2013)); DRC (resolutions 2098 (2013) and 2147 (2014)); and South Sudan (resolutions 2206 (2015) and 2304 (2016)).

${ }^{33}$ Williams, The R2P, Protection of Civilians, 539.

${ }^{34}$ Edward C. Luck, "From Promise to Practice: Implementing the Responsibility to Protect," in The Responsibility to Protect, eds. Jared Genser and Irwin Cotler (Oxford: Oxford University Press, 2012), 85-106. On the statist orientation of the original conception of R2P, see Luck and Luck, Individual Responsibility. 
section on "Violent Extremism and Atrocity Crimes." 35

The mother of all muddles, however, has been the UN's conflation of conflict prevention and atrocity prevention. ${ }^{36}$ When Secretary-General Kofi Annan proposed the world body's first post and action plan to prevent genocide in 2004, to mark the tenth anniversary of the Rwandan genocide, he apparently had no inter-governmental mandate to do so. Instead, he cited a Security Council resolution on conflict prevention, which responded to his report on conflict prevention. Neither document addressed the matter of atrocity or genocide prevention, despite the two mea culpa reports in 1999 on the organization's failures in Rwanda and Srebrenica. ${ }^{37}$ For the UN, the temptation to make atrocity prevention a subset of conflict prevention and resolution can be overwhelming. The Charter has countless references to preventing and resolving conflicts and, as noted above, not one to genocide or mass atrocities. The UN-both its Secretariat and its intergovernmental organs - is highly sophisticated and experienced in the former and little more than a novice in the latter. As they say, when your only tool is a hammer, everything looks like a nail. This would apply as much in the UN context to peaceful settlement as it does to the use of force in the US government.

Though it is undoubtedly true that more atrocities occur within armed conflicts than outside of them, experience has shown that horrific atrocities have occurred in a number of situations without armed conflict. During the period when the author was Special Adviser, these cases included, among others, Kenya (twice), Guinea (Conakry), and Kyrgyzstan, as well as the early stages of the violence in Libya and Syria. The etiology of mass atrocity crimes may sometimes include armed conflict, but that explains neither why atrocity crimes do not occur in all armed conflicts nor why they often take place in other circumstances. Prevention, therefore, demands a broader yet more dedicated understanding of the origins, course, termination, and possible reoccurrence of atrocity crimes. The very process of conflict resolution may tempt one or more parties to resort to the commission of atrocities to undermine the potential peace settlement, as may have been the case in both Rwanda and Srebrenica.

Conflating conflict prevention and atrocity prevention presents challenges for practice as well as for understanding and doctrine. For those engaged in mediation, keeping doors to the parties open will generally be perceived as more important than relaying uncomfortable messages about possible atrocity crimes. It was this author's experience that warnings from UN headquarters to parties in a conflict about behavior that was troubling from an atrocity prevention perspective were sometimes seen by SRSGs in the field and officials of the Department of Political Affairs in New York as too pointed or untimely. Governments are never eager to be told that their supporters or armed forces are committing atrocities, especially when they are facing armed opposition and their grip on power is threatened.

Sometimes quiet diplomacy, especially by the Secretary-General and/or senior regional figures, can make a difference in preventing atrocities, especially when the regime is divided or not fully committed to a genocidal project and the message is given relatively early. As noted above, the advent of the ICC has added a critical talking point about the decline of impunity and possible personal consequences for leaders in such situations, but that message tends to fall on deaf ears when the targeted leadership already sees the struggle in existential terms, has the backing of a permanent member of the Security Council, or the atrocities are being committed by extremist armed groups. From a conflict resolution perspective, however, the invocation of

\footnotetext{
${ }^{35}$ United Nations Security Council, Arria Formula Meeting on the Responsibility to Protect and Non-State Actors, December 14, 2015. The statement by this author is available on the web site of the Global Centre on the Responsibility to Protect. United Nations, Report of the Secretary-General, United Nations and Conflict Prevention: A Collective Recommitment, September 25, 2015 (UN Doc. S/2015/730), 9, paras., 32-34.

${ }^{36}$ Alex J. Bellamy, "Operationalizing the 'Atrocity Prevention Lens': Making Prevention a Living Reality," in Reconstructing Atrocity Prevention, eds. Sheri P. Rosenberg, Tibi Galis, and Alex Zucker (New York: Cambridge University Press, 2016), 67-69; Ruben Reike, "Conflict Prevention and R2P," in Oxford Handbook of the Responsibility to Protect, eds. Alex J. Bellamy and Tim Dunne (Oxford: Oxford University Press, 2016), 581-603; Edward C. Luck, "Getting There, Being There," in Oxford Handbook of the Responsibility to Protect, eds. Alex J. Bellamy and Tim Dunne (Oxford: Oxford University Press, 2016), 297-299.

${ }^{37}$ Luck, Getting There, Being There, 294-296.
} 
possible post-conflict ICC referrals may be regarded as a deterrent to a peaceful settlement that could leave leaders vulnerable to prosecution. In sum, when conflict prevention and atrocity prevention narratives converge, they can be mutually reinforcing, but often quite the opposite has been the case.

\section{Implications}

As the foregoing discussion underscores, the fact that the United Nations is pursuing so many related agendas simultaneously presents both opportunities and challenges for atrocity prevention efforts. There is no shortage of symbiotic possibilities, both in the field and at headquarters. But it is difficult to pursue so many policy streams at the same time and in the same place, as policy coherence tends to be far more difficult to achieve than surface-level coordination. Early warning, in this author's experience, is much less of a problem than assessment and framing. Policy makers with different responsibilities are likely to read the same information flows in distinct ways. What are the frameworks and patterns within which policy makers understand, sort, and prioritize the information before them? Why was Rwanda framed chiefly as a matter of implementing the Arusha accords rather than of preventing a massive genocide? Why was it believed that Serbian forces would not test the Security Council's will to enforce the safe areas it had established? Why was Sri Lanka regarded as a primarily humanitarian matter? And why were the early responses to the growing violence in Syria couched as a question of regime change rather than as a question of changing regime behavior and addressing the longer-term risks of mass atrocities, including against the ruling largely Alawite minority? Can atrocity prevention perspectives, given their chronically weak institutional positions, even get a voice at the key decision-making tables?

In this regard, the question of mainstreaming R2P and genocide prevention concerns presents risks as well as opportunities. In his final report on R2P, Secretary-General Ban was anything but ambivalent. The United Nations," he asserted, "must redouble its own efforts to mainstream the responsibility to protect. Faced with mounting challenges on multiple fronts, business as usual will not be sufficient." 38 The common theme from the multiple reviews of related UN work in 2015-2016, he underscored, was prevention. Fair enough, but the price of gaining the benefits of wider institutional visibility and greater conceptual coherence cannot be that atrocity prevention becomes just part of the bureaucratic checklist of other, more robust, institutional mandates. In the process of mainstreaming, it is essential that the singular perspective of atrocity prevention not be lost. The goal must not be the typical bureaucratic blending of messages - for which the UN is well known--but to maintain a distinctive and sometimes obnoxious voice for the prevention of mass atrocities. It has been - and will continue to be-hard to have it both ways.

Finding a distinct voice can be particularly difficult at the stage of structural prevention, when states under stress are not yet at a crisis point. As this author commented in 2001, in the context of conflict prevention, structural prevention strategies can confront a "dilemma of comprehensiveness" in which so many factors are perceived as potentially relevant that there is no basis for coherent priority setting or policy making. ${ }^{39}$ If everything is critical, then nothing is. More recently, the UN's joint office on genocide prevention and R2P developed a Framework of Analysis for Atrocity Crimes that is being employed with increasing frequency around the UN system. ${ }^{40} \mathrm{As}$ a checklist, it has some merit. But, with 14 risk factors and 143 indicators, the Framework does not provide a clear basis for determining the relative weight of the various factors and indicators. Most importantly, it lacks a dynamic dimension and a sense of which of these elements matter the most in which situations. For those decision makers charged with making quick and critical decisions in situations of acute concern, an over-reliance on such generic lists or templates could lead to the overlooking of those characteristics that make each situation unique.

\footnotetext{
${ }^{38}$ United Nations Secretary-General, Mobilizing Collective Action, 17, para. 60.

${ }^{39}$ Edward C. Luck, "Prevention: Theory and Practice," in From Reaction to Conflict Prevention: Opportunities for the UN System, eds. Fen Osler Hampson and David Malone (Boulder: Lynne Rienner, 2001), 256. Bellamy, Operationalizing the 'Atrocity Prevention' Lens, 65-66.

${ }^{40}$ United Nations Secretary-General, Mobilizing Collective Action, 12, para. 41.
} 
For these reasons, it is understandable that policy makers tend to put a premium on operational over structural prevention. Early engagement with societies under stress can be helpful for developing familiarity with the local dynamics and for gaining a modicum of mutual trust. Being engaged, however, is not the same thing as making a difference when push comes to shove. Mass atrocities are not spontaneous events. They require some degree of planning and mobilization, flowing from a series of destructive choices over time. The United Nations, regional arrangements, neighbors, influential governments, and civil society need to recognize opportunities to interrupt and disrupt such a chain of decisions and actions before they become irreversible. Some regimes and armed groups, of course, are determined to take such a course and cannot be dissuaded. Others, however, are reachable and perhaps persuadable through some combination of reason, carrots, and credible sticks. Local partners can be invaluable, particularly from civil society, media, clergy, the private sector, and parliaments. Where no such partners can be engaged because of the authoritarian or totalitarian nature of the political and security systems, as in Syria or the DPRK, respectively, then external actors have much less to work with and less chance of making a difference.

In all of this, getting the framing right is essential. That is why this author based the SecretaryGeneral's R2P implementation strategy on the premise of "early and flexible response tailored to the specific needs of each situation." ${ }^{\prime 11}$ That is also why efforts to smooth out R2P's rough edges so that it can blend better with other UN mandates pose the risk of missing the most valuable and distinctive elements of atrocity prevention work. This was not meant to be a comfortable, inoffensive quest. Crafting the most productive conceptual and working relationships between atrocity prevention and its conflict prevention, peacekeeping, human rights, and humanitarian cousins may take some time. As even Goldilocks discovered, it takes patience to find the right fit. But the effort is worth it.

How these conceptual, doctrinal, and institutional matters are resolved will matter far beyond the confines of the world body. As discussed earlier, the UN's unmatched political legitimacy and legal authority mean that what it does and does not do, where it does or does not speak out, matter much more than its deficits in material capacities would suggest. It is not a marginal player when it comes to atrocity prevention, in operational as well as normative terms, because of its catalytic role in encouraging regional and sub-regional bodies, governments, and civil society to step up when atrocities are threatened and societies are under stress. Each time the UN fails to utilize its voice or to try to make a difference, it feeds cynicism about the prospects for preventing mass atrocities and makes such crimes appear to be normal, if not acceptable. The world body, in that regard, has an enduring obligation to keep hope alive.

When costs and risks are high, the UN may have trouble rousing others to action, especially when its own Security Council is divided. But it has a responsibility to try to make a difference. Time has shown that the absence of its voice can be deafening when it decides to look the other way, as in Cambodia, Rwanda, and Sri Lanka. Each of its absences from the struggle for prevention, just as its operational shortcomings, tends to undermine both its moral authority/legitimacy and the strength of the norms, purposes, and principles for which it stands. In atrocity prevention, people and governments expect the UN to demonstrate moral and political leadership. And they notice when it fails to do so.

\section{Remedies}

Any honest enumeration of lessons learned about how to do atrocity prevention better is bound to be both short and speculative. The base of experience is recent and scattered. Trying to prevent mass atrocities is a recent endeavor, whether by governments, international institutions, or civil society. The United Nations did not even begin to articulate a strategy - and that just to prevent genocideuntil 2004. Not surprisingly, the learning curve has proven to be quite steep. No one who has tried to curb atrocities could ever claim it to be an easy or assured task. We are still learning how to do it. It is essential to retain a profound sense of modesty about what has been accomplished and about

${ }^{41}$ United Nations, Secretary-General Defends, Clarifies 'Responsibility to Protect' at Berlin Event on 'Responsible Sovereignty: International Cooperation for A Changed World," July 15, 2008 (UN Doc. SG/SM/11701). 
what future prospects look like. Vulnerable populations should not expect the United Nations to be anything close to a miracle worker, as it has at best proven to be a sometimes partner and/or catalyst to prevention and, less often, to protection.

R2P, in this author's view, offered two essential elements, both of which remain works in progress. One was to underscore that the prevention of atrocity crimes imposes both individual and collective responsibilities. Neither side of this equation will get far without the other. Notions of collective responsibility bring collective action problems. As the UN illustrates all too well, in this and most other areas, collective undertakings offer myriad opportunities for passing the buck. Nevertheless, as noted at the outset, there is reason to believe that the unique political legitimacy and legal authority offered by the United Nations and other inter-governmental bodies outweigh the collective action dilemmas that multilateral approaches to problem-solving entail. Only occasionally do other, more unilateral, avenues offer feasible and sustainable alternatives. The collective action dilemmas associated with genocide prevention and R2P at the world body led this author to emphasize the need for a parallel assumption of an individual responsibility to protect. ${ }^{42}$ As discussed above, the Secretariat can, and often has, acted without specific mandates from the Security Council or other inter-governmental organs. Obviously, the best chance of making a difference is when both individual and collective responsibilities are triggered at the UN and it has willing partners at the regional, national, and local levels.

The second essential element offered by R2P was the possibility of drawing much broader public, political, and media interest to prevention and protection issues. The fact that the assembled heads of state and government at the 2005 World Summit endorsed R2P at a time when they could not agree on many other matters was, in and of itself, quite remarkable. The Secretary-General's 2009 implementation report generated the longest debate on any question in the General Assembly that year, and there have been reports and Assembly debates (informal interactive dialogues) every year since. The Security Council has referred to R2P in 62 resolutions as of June 2017, with the frequency actually accelerating since the controversies over the use of force in Libya in $2011 .{ }^{43}$ The academic and policy literature on R2P seems endless.

Much of the commentary has, naturally, been critical, but the essential point is that the advent of R2P has undoubtedly spurred far more attention and analysis to the question of how to prevent atrocity crimes and protect populations than had been achieved over the more than a half century between the agreement on the Genocide Convention in 1948 and the ICISS report introducing R2P in 2001. Whether that momentum is sustainable, however, remains an open question. The progress with parliamentarians has been decidedly uneven and sporadic, and the discouraging developments in Syria, Yemen, and South Sudan appear to have had a dampening effect. As of spring 2017, 59 governments had appointed R2P focal points, but there is little uniformity in their backgrounds or assignments. ${ }^{44}$ It may be that too much of the action has been at the UN in New York and too little in national capitals.

Atrocity prevention and R2P continue to be much more political than technical or institutional challenges, though progress on the latter could affect political calculations about what is possible and what the associated costs and risks of engagement are likely to be. Among the steps that could be helpful at this point would be:

- Assigning a higher priority to identifying, discouraging, and disrupting incitement.

- Developing global, regional, and national doctrine and capacities for preventive deployments of peacekeepers and monitors in countries under stress, such as was done in the Former Yugoslav Republic of Macedonia and Burundi.

- Revisiting the initial conception of the PBC as an inter-governmental body concerned with situations under stress and sliding towards conflict and possible atrocities as well as those

\footnotetext{
${ }^{42}$ Luck and Luck, The Individual Responsibility to Protect.

${ }^{43}$ This number is drawn from the web site of the Global Centre for R2P, which maintains a running list of the relevant resolution texts. The Centre counts R2P references in 17 statements-PRSTs - by the President of the Council as well. The International Coalition for R2P also tracks the Council references on its web site.

${ }^{44}$ For updates, see the web site of the Global Centre for R2P, which acts as the secretariat for the focal points network.
} 
emerging from conflict.

- Reviving the convening function given to the Special Advisers for Genocide Prevention and for R2P in the Secretary-General's 2010 report on early warning and assessment. ${ }^{45}$

- Initiating joint UN/African Union and UN/European Union assessments of lessons learned from past efforts to prevent mass atrocities and of ways to enhance their collaboration in operational prevention efforts in the future, including responding to incitement and undertaking preventive deployments individually or jointly.

- Preparing a report by Secretary-General Guterres on how atrocity prevention fits thematically, operationally, and institutionally into his announced intention to prioritize prevention strategies in the work of the United Nations.

None of these or similar steps could make much difference, however, without a more far-reaching reassessment of the UN's institutional culture when it comes to preventing atrocities and protecting populations. Despite three wrenching mea culpa reports on Rwanda, Srebrenica, and Sri Lanka, there remains a deep-seated resistance in the Secretariat and among the Member States to absorbing the hard lessons of those fundamental failures. There have been two entrenched assumptions: one, that the UN's natural and proper stance towards parties should be one of impartiality and two, that the use of force should always be a last resort. Neither assumption, in this author's view, conforms with the provisions or spirit of the Charter. Each has its place, but should not be applied uniformly, especially when the risk of mass atrocities appears high and imminent.

The 2015 report of the Secretary-General on conflict prevention properly heralds the value of impartiality for providing "access to a diverse number of stakeholders with whom we can build trust and engage." ${ }^{46}$ But it goes too far in asserting that the UN's unique role stems from "impartiality and the legitimacy derived from the principles of the Charter." ${ }^{47}$ In fact, the Charter never uses the term "impartiality" or anything similar, as this is an attribute for conflict resolution, not a founding principle of the organization. There are times when the UN should be impartial and others when it needs to take sides. To avoid the League of Nations' debilitating shortage of will and capacity, the founders of the UN did their best to prepare it to organize resistance to aggression. In his report on The Fall of Srebrenica, Secretary-General Annan criticized the "the general tendency to assume that the parties were equally responsible for the transgressions that occurred," which led to negotiations with those planning and executing atrocities that "amounted to appeasement." 48 He faulted the "institutional ideology of impartiality even when confronted with attempted genocide." ${ }^{49}$ And he concluded that "the men who have been charged with this crime against humanity reminded the world and, in particular, the United Nations, that evil exists in the world. They taught us also that the United Nations global commitment to ending conflict does not preclude moral judgements, but makes them necessary." 50

The founders would also be surprised to learn that it has become customary at the UN to assert that the use of force should always be a last resort. That is far from what they had in mind in crafting the Charter. In preparing the Secretary-General's 2009 strategy for implementing R2P, this author used the phrase "measure of last resort" instead. This was meant to convey the notion that force was not a preferred tool, given its costs, risks, and consequences, but that it should not be relegated to consideration as a final, desperate, alternative when all else has failed. The stance of some Member States and members of the Secretariat that force should be regarded as a last resort in a sequential or chronological manner runs counter to the goal of protecting populations and to Secretary-General Ban's early and flexible response strategy. Regarding the latter, SecretaryGeneral Annan's report took his predecessor to task for speaking "against a 'culture of death"'

\footnotetext{
${ }^{45}$ United Nations, Report of the Secretary-General (as drafted by this author), Early Warning, Assessment and the Responsibility to Protect, July 14, 2010 (UN Doc. A/64/864), 7, para. 18.

${ }^{46}$ United Nations, United Nations and Conflict Prevention, 4, para. 12.

${ }^{47}$ Ibid.

${ }^{48}$ United Nations, Fall of Srebrenica, 107, paras. 496 and 500.

${ }^{49}$ Ibid., 108, para. 505.

${ }^{50}$ Ibid., 108, para. 506.
} 
and for "arguing that peace should be pursued only through non-military methods." 51 He acknowledged that "errors of judgement were made-errors rooted in a philosophy of impartiality and non-violence wholly unsuited to the conflict in Bosnia." 52 And he pointed to "the pervasive ambivalence within the United Nations regarding the role of force in the pursuit of peace." 53

More than two decades after these horrific failures to protect, the debate over R2P illustrates how deeply these inhibitions continue to affect the effort to articulate and implement an effective UN strategy for curbing mass atrocities. For instance, Brazil's 'responsibility while protecting' (RWP) proposal, whatever its other merits, would have imposed both a sequenced approach to R2P implementation and a series of standards for Security Council authorization for the use of force in stopping atrocities that do not exist for the Council's employment of force for other purposes. ${ }^{54}$ That approach certainly would not have been among the lessons drawn from Rwanda and Srebrenica.

Given these multiple obstacles, some imposed and others self-generated, it is striking that the United Nations has had any success at all in helping to prevent mass atrocities. It has undoubtedly underperformed, but its assets, particularly in terms of legitimacy and authority, are both real and sustainable. There are unrealized capacities on the Secretariat side and the Member States could do much more if they had greater confidence that their investments in the world body would pay off and if they generally placed a higher priority on preventing atrocities and protecting populations. If there is good news about unrealized potential, it is that there are substantial opportunities waiting to be pursued. At every level-individual, local, national, regional, and global-curbing atrocities is a relatively new enterprise that could take decades to nurture and develop. Possible synergies abound. It is time to stop pointing fingers, to start taking responsibility, and to get to work on building the kind of partnerships that could make a real difference over time.

\section{Bibliography}

Bellamy, Alex J. and Tim Dunne, editors. Oxford Handbook of the Responsibility to Protect. Oxford: Oxford University Press, 2016. https://doi.org/10.1093/oxfordhb/9780198753841.001.0001

Bellamy, Alex J. "Operationalizing the 'Atrocity Prevention Lens': Making Prevention a Living Reality." In Reconstructing Atrocity Prevention, edited by Sheri P. Rosenberg, Tibi Galis, and Alex Zucker, 61-80. New York: Cambridge University Press, 2016.

"UN Security Council." In Oxford Handbook of the Responsibility to Protect, edited by Alex J. Bellamy and Tim Dunne, 249-268. Oxford: Oxford University Press, 2016.

and Edward C. Luck, The Responsibility to Protect: From Promise to Practice. Cambridge, UK: Polity Books, forthcoming.

Benner, Thorsten. "Brazil as a Norm Entrepreneur: The ‘Responsibility While Protecting' Initiative." Working Paper. Berlin: Global Public Policy Institute, March 2013.

Borger, Julian. "Russia Denied Membership of UN Human Rights Council," The Guardian, 28 October 2016.

Chesterman, Simon. "Relations with the Secretary-General." In The UN Security Council in the 21st Century, edited by Sebastian von Einsiedel, David M. Malone, and Bruno Stagno Ugarte, 443-456. Boulder: Lynne Rienner, 2016.

Gilmour, Andrew. "The Future of Human Rights: A View from the United Nations." Ethics and International Affairs 28, no. 2 (2014): 239-250. https://doi.org/10.1017/S0892679414000240

Guéhenno, Jean-Marie. The Fog of Peace: A Memoir of International Peacekeeping in the 21st Century. Washington, DC: Brookings Institution Press, 2015.

\footnotetext{
${ }^{51}$ Ibid., 107, para. 497.

${ }^{52}$ Ibid., 107, para. 499.

${ }^{53}$ Ibid., 108, para. 505.

${ }^{54}$ Brazil's RWP concept paper can be found at United Nations, A/66/551-S/2011/701, November 11, 2011. For analysis and commentary, see Thorsten Benner, "Brazil as a Norm Entrepreneur: The 'Responsibility While Protecting' Initiative," (Berlin: Global Public Policy Institute Working Paper, March 2013); Monica Herz, "Brazil and R2P: Responsibility While Protecting," in The International Politics of Human Rights: Rallying for the R2P Cause?, eds. Mónica Serrano and Thomas G. Weiss (London: Routledge, 2014), 107-128.
} 
Guterres, António. "Secretary-General-Designate Remarks to the General Assembly on Taking the Oath of Office." Speech, New York, December 12, 2016. United Nations.

Herz, Monica. "Brazil and R2P: Responsibility While Protecting." In The International Politics of Human Rights: Rallying for the R2P Cause?, edited by Monica Serrano and Thomas G. Weiss. 107-128. London: Routledge, 2014.

Kikoler, Naomi. "Guinea: An Overlooked Case of the Responsibility to Protect in Practice." In The Responsibility to Protect: Overcoming the Challenge of Atrocity Prevention, edited by Serena K. Sharma and Jennifer M. Welsh, 304-323. Oxford: Oxford University Press, 2015. https://doi.org/10.1093/acprof:oso/9780198717782.003.0012

Kingsbury, Damien. "Sri Lanka." In The Responsibility to Protect: The Promise of Stopping Mass Atrocities in Our Time, edited by Jared Genser and Irwin Cotler, 298-315. Oxford: Oxford University Press, 2012.

Kuperman, Alan J. "The Moral Hazard of Humanitarian Intervention: Lessons from the Balkans." International Studies Quarterly 52, no. 1 (March 2008): 49-80. https://doi.org/10.1111/j.14682478.2007.00491.x

Kurtz, Gerrit. With Courage and Coherence: The Human Rights Up Front Initiative of the United Nations. Berlin: Global Public Policy Institute, July 2015.

Luck, Edward C. "Getting There, Being There: The Dual Roles of the Special Adviser." In The Oxford Handbook of the Responsibility to Protect, edited by Alex J. Bellamy and Tim Dunne, 288-314. Oxford: Oxford University Press, 2016.

. "From Promise to Practice: Implementing the Responsibility to Protect." In The Responsibility to Protect: The Promise of Stopping Mass Atrocities in Our Time, edited by Jared Genser and Irwin Cotler, 85-106. Oxford: Oxford University Press, 2012.

. "Prevention: Theory and Practice." In From Reaction to Conflict Prevention: Opportunities for the UN System, edited by Fen Osler Hampson and David Malone, 251- 271. Boulder: Lynne Rienner, 2001.

--------. "Prospects for Institutional Renovation and Reform." In The Oxford Handbook on the United Nations, 2nd ed., edited by Thomas G. Weiss and Sam Daws. Oxford: Oxford University Press, forthcoming).

. "Roots of Ambivalence: The United Nations, Genocide, and Mass Atrocity Prevention." In Policies and Practices for Preventing Atrocities, edited by Ted Robert Gurr and Barbara Harff. London: Routledge, forthcoming.

and Dana Zaret Luck. “The Individual Responsibility to Protect." In Reconstructing Atrocity Prevention, edited by Sheri P. Rosenberg, Tibi Galis, and Alex Zucker, 237-242. New York: Cambridge University Press, 2016.

Nackers, Kimberly. "Framing the Responsibility to Protect in the 2009 Sri Lanka Civil War." Global Responsibility to Protect 7, no. 1 (2015): 81-108. https://doi.org/10.1163/1875984X-00701005

. "Sri Lanka." In Oxford Handbook of the Responsibility to Protect, edited by Alex J. Bellamy and Tim Dunne, 876-894. Oxford: Oxford University Press, 2016. https://doi.org/10.1093/ oxfordhb/9780198753841.001.0001

Orchard, Phil. "Revisiting Humanitarian Safe Areas for Civilian Protection." Global Governance, 20 (2014): 55-75.

Power, Samantha. "A Problem from Hell:" America and the Age of Genocide. New York: Harper Collins, 2002.

Reike, Ruben. "Conflict Prevention and R2P." In Oxford Handbook of the Responsibility to Protect, edited by Alex J. Bellamy and Tim Dunne, 581-603. Oxford: Oxford University Press, 2016),

Slim, Hugo. "Saving Individuals from the Scourge of War: Complementarity and Tension between R2P and Humanitarian Action." In Oxford Handbook of the Responsibility to Protect, edited by Alex J. Bellamy and Tim Dunne, 545-560. Oxford: Oxford University Press, 2016.

United Nations. Charter of the United Nations and Statute of the International Court of Justice. June 26, 1945. United Nations.

--------. General Assembly Resolution 60/1, 2005 World Summit Outcome. October 24, 2005. UN Doc. $\mathrm{A} / \mathrm{RES} / 60 / 1$.

--------. Resolution Adopted by the General Assembly on 21 December 2016. UN Doc. A/RES/71/248. 
---------. Report of the Independent Inquiry into the Actions of the United Nations during the 1994 Genocide in Rwanda. December 16, 1999. UN Doc. S/1999/1257.

--------. Report of the Panel on United Nations Peace Operations. August 21, 2000. UN Doc. A/55/305-S/2000/809.

-------. Report of the Secretary-General, A Vital and Enduring Commitment: Implementing the Responsibility to Protect. July 13, 2015. UN Doc. A/69/981-S/2015/500.

-------. Report of the Secretary-General, Early Warning, Assessment and the Responsibility to Protect. July 14, 2010. UN Doc. A/64/864.

--------. Report of the Secretary-General, Implementing the Responsibility to Protect. January 12, 2009. UN Doc. A/63/677.

-------. Report of the Secretary-General, Mobilizing Collective Action: The Next Decade of the Responsibility to Protect. July 22, 2016. UN Doc. A/70/999-S/2016/620.

--------. Report by the Secretary-General, Prevention of Armed Conflict. June 7, 2001. UN Doc. A/55/985-S/2001/574.

--------. Report of the Secretary-General, Status of the Human Rights Treaty Body System, July 18, 2016. UN Doc. A/71/118.

---------. Report of the Secretary General pursuant to General Assembly resolution 53/35. The Fall of Srebrenica. November 15, 1999. UN Doc. A/54/549.

---------. Report of the Secretary-General, United Nations and Conflict Prevention: A Collective Recommitment. September 25, 2015. UN Doc. S/2015/730.

--------. Report of the Secretary-General's High-level Panel on Threats, Challenges and Change, $A$ More Secure World: Our Shared Responsibility. 2004. United Nations Department of Public Information.

-------. Secretary-General Defends, Clarifies 'Responsibility to Protect' at Berlin Event on 'Responsible Sovereignty: International Cooperation for A Changed World. July 15, 2008. UN Doc. SG/ $\mathrm{SM} / 11701$.

United Nations Security Council. Arria Formula Meeting on the Responsibility to Protect and Non-State Actors. December 14. 2015.

--------. Letter Dated 30 December 2008 from the Permanent Representative of South Africa Addressed to the President of the Security Council. December 31, 2008. UN Doc. S/2008/836.

Waller, James. Confronting Evil: Engaging the Responsibility to Prevent Genocide. Oxford: Oxford University Press, 2016.

Williams, Paul D. "The R2P, Protection of Civilians, and UN Peacekeeping Operations." In Oxford Handbook of the Responsibility to Protect, edited by Alex J. Bellamy and Tim Dunne, 524-544. Oxford: Oxford University Press, 2016.

Zaum, Dominik. "The Security Council, the General Assembly, and War: The Uniting for Peace Resolution." In The United Nations Security Council and War: The Evolution of Thought and Practice Since 1945, edited by Vaughan Lowe, Adam Roberts, Jennifer Welsh, and Dominik Zaum, 154-174. Oxford: Oxford University Press, 2008. 